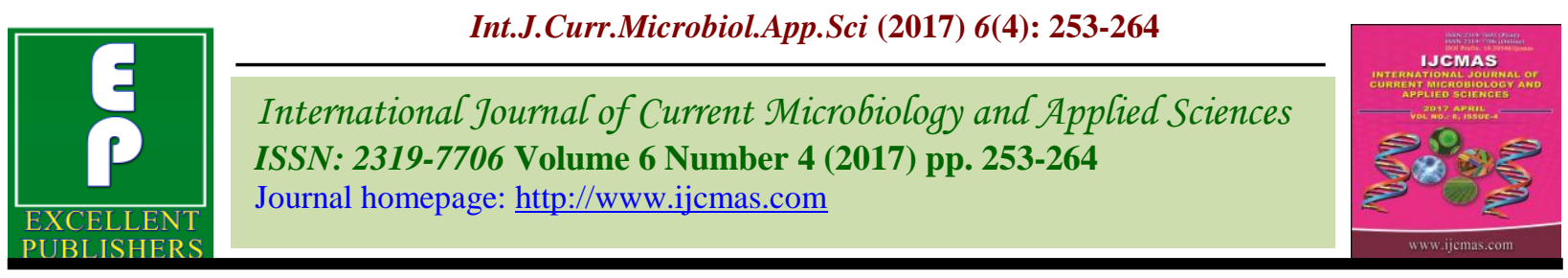

Original Research Article

https://doi.org/10.20546/ijcmas.2017.604.029

\title{
Biochemical, Nutritional Profiling and Optimization of an Efficient Nucleic Acid Isolation Protocol from Recalcitrant Tissue of Wild Edible Fruit Antidesma bunius L. Spreng
}

\author{
Sushma Khomdram ${ }^{1,2 *}$, Shyamananda Arambam ${ }^{2}$, \\ Sharmistha Barthakur ${ }^{2}$ and Guruaribam Shantibala Devi ${ }^{1}$ \\ ${ }^{1}$ Department of Life Sciences, Manipur University, Canchipur 795003, Manipur, India \\ ${ }^{2}$ National Research Centre on Plant Biotechnology, Pusa Campus, New Delhi 110012, India \\ *Corresponding author:
}

\author{
A B S T R A C T
}

Keywords

Biochemical analysis, DNA, Antidesma bunius, Wild fruit.

Article Info

Accepted:

02 March 2017

Available Online:

10 April 2017
Antidesma bunius known as 'currant tree' is a popular fruit in several Asian countries. During our exploration of wild fruits of Manipur, India, we identified this edible fruit growing naturally in their wild habitat. An exhaustive biochemical analyses revealed very high concentration of mineral contents relative to other well known fruits. Correlation analysis showed significant relationship between ascorbic acid content and antioxidant oxidant activity. A protocol for isolation of high quality DNA from mature leaves of the fruit tree which is very rich in polyphenols and secondary metabolites was also standardized for the very first time with high purity and quality genomic DNA amenable to downstream initiation of any molecular work in this species. Our results bring further potential and necessity of popularizing this fruit amongst general consumers.

\section{Introduction}

Wild fruit plant Antidesma bunius of phyllanthaceae family is naturally distributed throughout Southeast Asia. The fruit is called bignay in Philippines, berunai in Malaya, hooni in Indonesia, mao luang in Thailand, kho lien tu in Laos, choi moi in Vietnam, moikin and chunka by the Queensland (Australia). In English the fruit tree is known as -Chinese laurel, currant tree, nigger's cord, and salamander tree. The fruit is native and common in wild form in the lower Himalayas in India, Southeast Asia, northern Australia, Sri Lanka, Burma, Indo-China, China, Thailand, and Indonesia. It thrives in Java from sea-level 0 to $4,000 \mathrm{ft}(1,200 \mathrm{~m})$. There are about 100 species and the highest number is in South-East Asia, of which 18 species are native to Thailand (Hoffmann, 1999).

Combating malnutrition and hidden hunger is a growing issue in today's contemporary world. Fruits and vegetable are excellent source of vitamins and mineral nutrition. To tackle malnutrition among infants, children's as well as adults one approach is making locally available affordable sources of vitamins and mineral popular and familiar among the consumers. The fruits and leaves of Antidesma bunius are consumed as dietary supplement in certain countries viz. Malaysia, 
Indonesia, Philippines and Thailand. The fruits can be made into jam or jelly, or fermented into wine with good physiological properties (Ma et al., 2013). The leaves are eaten as vegetable and used as a traditional medicine for the treatment of skin disorder, syphilis and snakebites (Sosef and Prawirohatmodjo, 1998; Antony et al., 2010; Hazarika et al., 2012). The leaves and barks of this fruits contain anti-toxins which are used in tribal areas as human herbal medication and also as traditional remedies for animals like sheep and goats in West Java (Tri, 1991; Jethro et al., 2011). The fruits tree was also used in treatment of different illnesses from colds to cancer (Magsino, 2003). The fruits are considered a rich source of phenolics, organic acids, anthocyanins and other flavonoids (Samappito and Butkhup, 2008b). The isolation of biflavone amentoflavone and the $\mathrm{C}$ glycoside viccinin II of phenolic compounds was listed for the first time from Antidesma bunius species (Mona et al., 2013). Contain of a possible substances having cytotoxic activity from the fruits and leaves of currant trees was also reported (Jose et al., 2005). Studies on plants species of this fruits collected from Vietnam showing cytotoxicity against the HT-29 human colon cancer line and against MCF-7 human breast cancer cell lines were also reported (Li et al., 2011, Anas et al., 2012). Genetic divergence taste responsiveness for phenylthiocarbamide was confirmed in this fruit tree (Henkin and Gillis, 1997). Some of the constituents from this berry plant have been patented by Avon for skin care products that stimulate production of micro fibril-associated glycoprotein 1(Edward, 2012). Recent study indicates that Antidesma bunius fruit extract can serve as a novel alternative source of organic pesticide effective against the ladybird pest (Rosario et al., 2014).

For molecular profiling of any organism, isolation of pure, intact and high quality DNA is the first crucial steps. A good extraction procedure for the isolation of DNA should yield adequate and intact DNA of reasonable purity (Puchooa, 2004). The degree of purity and quantity varies between applications. Polysaccharides and polyphenols are the major components that hinder DNA extraction processes. They are not completely removed during classical extraction protocols and remain as contaminants in the final DNA preparations thereby causing non- amplifiable DNA in PCR reactions by inhibiting Taq activity and also interfere with restriction digestion (Porebski et al., 1997). Although various methods for DNA isolation from plant having high levels of secondary metabolites have been reported; we were not successful with these protocols. We have developed the present method by introducing several modifications in the CTAB method which elucidated good quality DNA.

Manipur state of India is one of the mega biodiversity hot-spots regions of the world (Myer et al., 2000). The state is endowed with various wild fruit species distributed naturally. Antidesma bunius known locally as heiyen are grown in wild environment in the Manipur valley with elevation of 750 to $900 \mathrm{mMSL}$ during the rainy season from July to October. The fruit has single flat seed and is sour in taste when ripe. Except for a few reports in recent times there has been no systematic exploration of these fruit (Sushma and Shantibila, 2010; Haripyaree et al., 2010). Comprehensive bio chemical evaluation of Antidesma bunius and standardization of genomic DNA isolation is perhaps the first report from this region. This will be a prelude to further molecular and various phytonutrient explorations of wild edible Antidesma bunius

\section{Materials and Methods}

The wild fruit sample and leaves of Antidesma bunius were collected from the valley region of Manipur and identified at Botanical Survey of India (BSI), Eastern 
Regional Central, Woodlands, Laitumkhrah, Shillong, Meghalaya, India.

\section{Biochemical estimations}

The proximate biochemical analyses were carried out using standard protocols for estimation of total soluble protein using BSA as standard (Lower et al., 1951) total soluble sugar by anthrone reagent and reducing and non-reducing sugar (Dudois et al., 1951, Nelson, 1944, Malhotra and Sarkar, 1979). The moisture content of the fruit was determined by AOAC (1970)method and ascorbic acid protocol using $4 \%$ oxalic acid as extraction medium and 2, 6- dichlorophenol indophenol dye chemical assay (Thimmaiah, 1999).

Antioxidant activity (AOA) was carried out by DPPH assay (Krings and Berger, 2001). For correlation analysis between Ascorbic acid content (AAC) and antioxidant activity (AOA) of the fruit samples, Pearson Correlation Coefficient was used. Elemental $\mathrm{Mg}, \mathrm{Fe}, \mathrm{Mn}, \mathrm{Cu}, \mathrm{Zn}$, Co were analysed by using Atomic absorption spectrophotometer (AAS) and $\mathrm{K}$ by flame photometry. The determination of $\mathrm{pH}$ was calibrated with $\mathrm{pH}$ meter using standard buffer solution after fruits were finely minced. For each point of estimation, three biological samples with three replicates were used.

\section{Standardization of DNA isolation, restriction and $\mathrm{PCR}$ analysis}

Chemicals for molecular biology work were obtained from Sigma (USA) and Bio Basic (Canada), restriction enzymes, Taq DNA Polymerases; DNA Ladders were obtained from New England Bio Lab (USA), RNaseA from Invitrogen (USA).

DNA was isolated from fresh matured leaf sample using modified CTAB (cetyl trimethyl ammonium bromide) extraction method (Murray and Thompson, 1980) In brief, $2 \mathrm{~g}$ of leaf tissue was ground in liquid nitrogen into powder form. Freshly prepared $2 \%$ extraction buffer (1M Tris-HCL; pH 8.0, 5M NaCL, 0.25 M EDTA; $\mathrm{pH} \quad 8.0,2 \%$ CTAB) containing $8 \% \quad \beta$-mercaptoethanol and $3 \%$ PVP was added.

The suspension was incubated at $65^{\circ} \mathrm{C}$ for $1 \mathrm{~h}$ with intermittent mixing. A 6 layers muslin cloth was used for filtration of the extract. Then equal volume of chloroform: isoamylalcohol (24:1) was added and mixed and centrifuged at $14000 \mathrm{rpm}$ at $20{ }^{\circ} \mathrm{C}$ for 10 min. To the aqueous phase $1 / 10$ th $3 \mathrm{M}$ $\mathrm{NaOAc}$ was added along with 2 volume of ice cold ethanol and incubated at $-20^{\circ} \mathrm{C} \mathrm{O} / \mathrm{N}$. DNA from aqueous layer was precipitated by adding $10 \mathrm{ml}$ chilled $95 \%$ ethanol. The mixture was centrifuged at $14000 \mathrm{rpm}$ at $20^{\circ} \mathrm{C}$ for $10 \mathrm{~min}$ to collect the DNA pellet. The pellet was washed with $70 \%$ ethanol and centrifuged at $14000 \mathrm{rpm}$ at $20^{\circ} \mathrm{C}$ for $10 \mathrm{~min}$. After drying the pellet at $37^{\circ} \mathrm{C}$ it was dissolved in $50 \mu \mathrm{l}$ Tris-Cl-EDTA (pH 8.0) buffer and checked in $0.8 \%$ agrose gel.

PCR amplification of DNA with housekeeping Actin gene primers from rice was carried out in a final 50ul volume of reaction mixture. Each reaction contained 50ng DNA, 1ul of taq DNA polymerase, $10 \mathrm{mM}$ dNTP mix, 1X Taq DNA polymerase buffer and 10pmol each forward 5'AGCGAGTCTTCATAGGGCGATTGT 3' and reverse primer 5 , TAGCTCTGGGTTC GAGTGGCATTT 3'. The reaction conditions were $95^{\circ} \mathrm{C}-3 \mathrm{~min} ; 35$ cycles at $94^{\circ} \mathrm{C}-50 \mathrm{sec}$, $68^{\circ} \mathrm{C}-50 \mathrm{sec}$, and $72^{\circ} \mathrm{C}-2 \mathrm{~min}$; and a final extension at $72^{\circ} \mathrm{C}$ for $10 \mathrm{~min}$. PCR products were subjected to $1.2 \%$ agarose gel electrophoresis in 0.5XTBE buffer, stained with ethidium bromide and photographed in a gel documentation system (Alpha imager). 


\section{Results and Discussion}

\section{Nutritional profiling of Antidesma bunius}

The Antidesma bunius plant and the fruits at various stages are shown in (Figure 1). Towards clarifying the nutritional status of wild edible Antidesma bunius of Manipur, we carried out a comprehensive estimation of various parameters which are shown in table 1. From the analysis, ascorbic acid content (AAC) was $7.80 \mathrm{mg} / 100 \mathrm{~g}$ fresh weight and antioxidant activity (AOC) as $\mathrm{IC}_{50} 1717.42$ $\mu \mathrm{g} / \mathrm{ml}$ showing significant Pearson correlation ship $(\mathrm{p}<0.05)$ between the two. Elemental analysis with AAS and flame photometry has shown good mineral content of the studied fruit. Macro - elements $\mathrm{K}$ and $\mathrm{Mg}$ was high with $450 \mathrm{mg} / 100 \mathrm{~g}$ and $193.25 \mathrm{mg} / 100 \mathrm{~g}$ respectively. In micro- elements, Mn was high having $21.8 \mathrm{mg} / 100 \mathrm{~g}$ followed by $\mathrm{Fe}$ $18.85 \mathrm{mg} / 100 \mathrm{~g}$, $\mathrm{Zn}-2.1 \mathrm{mg} / 100 \mathrm{~g}, \mathrm{Cu}-1.6$ $\mathrm{mg} / 100 \mathrm{~g}$ and Co $-0.1 \mathrm{mg} / 100 \mathrm{~g}$ respectively. High $\mathrm{pH}$ of 2.04 was observed in the fruit with moisture content $79.28 \%$. The total soluble sugar, non-reducing sugar, reducing sugar present were in reasonable amounts and the total soluble protein present was 1.64 $\mathrm{mg} / 100 \mathrm{~g}$.

\section{Nucleic acid isolation and analysis}

And as a first step for molecular study we have standardized a protocol for DNA isolation from the fruit leaves which was found very condensed with polyphenols and mucilaginous substances. Published methods of DNA isolation was proved unsuccessful and unreliable for this particular fruit plant (Roger and Bendich, 1988; Dellaporta et al., 1983; Doyle and Doyle, 1990) (Figure 2). Finally various steps with modifications from CTAB method, a successful protocol was standardized and good quality DNA band was obtained. We incorporated use of 6 layer muslin cloth for filtration after the extraction step and the DNA band of Antidesma bunius selected for molecular analysis has showed good quality DNA bands in $0.8 \%$ of agrose gel electrophoresis at above $10 \mathrm{kbs}$ and with $259.50 \mathrm{ng} 100 \mathrm{mg}^{-1}$ of tissues with our new method (Figure 2). Although the quantity was not very high, downstream quality checks were successful. Upon restriction digestion with enzymes Nco1, genomic DNA had shown good digestibility. The isolated DNA used for PCR analysis with housekeeping Actin gene primers showed the desired 200bp amplicon (Figure 2). This verifies that the isolated DNA of these wild fruit with the above protocol is of excellent quality, pure, intact and free of contaminants, like polyphenols and polysaccharides.

\section{pH, moisture and protein profiling}

The $\mathrm{pH}$ level of the fruit sample Antidesma bunius was found to be highly acidic compared to a study of Mao Lung (Antidesma bunius) from Phupan valley in Northeast Thailand having 3.51 (Samappito and Butkhup,2008b). Also the $\mathrm{pH}$ of Antidesma bunius found in Manipur is more acidic than fifteen Mao Luang cultivars found in Dipterocarp forest of Thailand (Samappito and Botkhup, 2008a; Luchai and Supachai, 2011), but comparable with initial day of harvest in different maturation stages studied in Mao Lung fruits having $2.20 \mathrm{pH}$ value. The Moisture content of Antidesma bunius was $79.18 \%$ which was very much compatible with 15 different cultivars of bignay berries namely: Sangkrow NO.2, Fapratan, Sangkrow NO.1, Maeloogdog, Phuchong, Sangkrow NO.4, Sangkrow NO.3, Sangkrow NO.5, Lompat, Nonkloy, Sangkrow NO.8, Kumlhai, Chomphupan, Sangkrow NO.7 and Yaiswang (Luchai and Supachai, 2008). 
Table.1 Biochemical analyses of wild edible Antidesma bunius fruit of Manipur along with Pearson correlation coefficient value. All values are presented with \pm SD of 3 replicate of 3 biological samples

Biochemical parameters

\begin{tabular}{|c|c|}
\hline Moisture \% & $79.18 \% \pm 0.26$ \\
\hline $\mathrm{pH}$ & $2.04 \pm 0.20$ \\
\hline Vitamin C mg/100g FW & $7.80 \pm 2.15$ \\
\hline Antioxidant activity $\mathrm{IC}_{50} \mu \mathrm{g} / \mathrm{ml}$ & $1717.42 \pm 203.7$ \\
\hline Protein $\mathrm{mg} / 100 \mathrm{~g}$ & $1.64 \pm 0.31$ \\
\hline Total soluble sugar $\mathrm{mg} / 100 \mathrm{~g}$ & $1.21 \pm 0.12$ \\
\hline Reducing sugar mg/100 g & $0.22 \pm 0.09$ \\
\hline Non- reducing sugar $\mathrm{mg} / 100 \mathrm{~g}$ & $0.99 \pm 0.08$ \\
\hline \multicolumn{2}{|l|}{ Minerals contents $\mathrm{mg} / 100 \mathrm{~g}$} \\
\hline Potassium & $450 \pm 0.04$ \\
\hline Magnesium & $193.25 \pm 54.5$ \\
\hline Iron & $18.85 \pm 0.06$ \\
\hline Manganese & $21.8 \pm 0.33$ \\
\hline Copper & $1.6 \pm 0.03$ \\
\hline Zinc & $2.1 \pm 0.03$ \\
\hline Cobalt & $0.1 \pm 0.06$ \\
\hline $\begin{array}{l}\text { Correlation between } \mathrm{AAC} \text { and } \mathrm{AOA} \\
\mathrm{r}(\mathrm{p}<0.05)\end{array}$ & -0.726 \\
\hline
\end{tabular}

Antidesma bunius L.Spreng 
Table.2 Relative analysis of elemental content of Antidesma bunius with reported values of well known fruits (Compiled from Cunningham et al., 2001). All values are shown as mg/100g

\begin{tabular}{|c|c|c|c|c|c|c|}
\hline Fruits & $\mathrm{K}$ & $\mathrm{Mg}$ & $\mathrm{Mn}$ & $\mathrm{Fe}$ & $\mathrm{Cu}$ & $\mathrm{Zn}$ \\
\hline A.bunius & 450 & 193.25 & 21.8 & 18.85 & 1.6 & 2.1 \\
\hline Watermelon & 158 & 11 & Trace & Trace & 0.4 & Trace \\
\hline Strawberry & 183 & 13 & Trace & 0.5 & Trace & Trace \\
\hline Raspberries & 228 & 1.5 & 22 & - & - & Trace \\
\hline Apricot & 283 & 0.8 & 12 & - & - & Trace \\
\hline Apple & 129 & 3 & Trace & 0.1 & Trace & Trace \\
\hline Banana & 358 & 29 & Trace & 0.4 & Trace & Trace \\
\hline Blueberries & 175 & 17 & 2 & 1 & Trace & 0.4 \\
\hline Cherries & 248 & 0.5 & 10 & - & - & Trace \\
\hline Grapefruit & 165 & 0.1 & 10 & - & - & 1 \\
\hline Kiwi & 326 & 0.3 & 13 & 0.3 & 0.3 & 0.3 \\
\hline Lemon & 193 & 9 & Trace & 0.1 & Trace & Trace \\
\hline Lime & 68 & 4 & Trace & 0.4 & Trace & Trace \\
\hline Lychee & 182 & 0.3 & 18 & - & - & 2 \\
\hline Mango & 143 & 11 & Trace & 0.2 & Trace & Trace \\
\hline Melon & 213 & 7.6 & Trace & Trace & Trace & Trace \\
\hline Orange & 154 & 10 & Trace & 0.2 & Trace & Trace \\
\hline Pear & 112 & 5 & Trace & 0.1 & Trace & Trace \\
\hline Pineapple & 180 & 0.4 & 17 & - & - & Trace \\
\hline Plum & 197 & 0.3 & 7 & - & - & Trace \\
\hline
\end{tabular}


Figure.1 Antidesma bunius L. Spreng, family phyllanthaceae, Common name- currant tree, local/Manipuri name -Heiyen; a) Fruit with tree; b) Flower; c) unripe fruit; d) Mature fruit
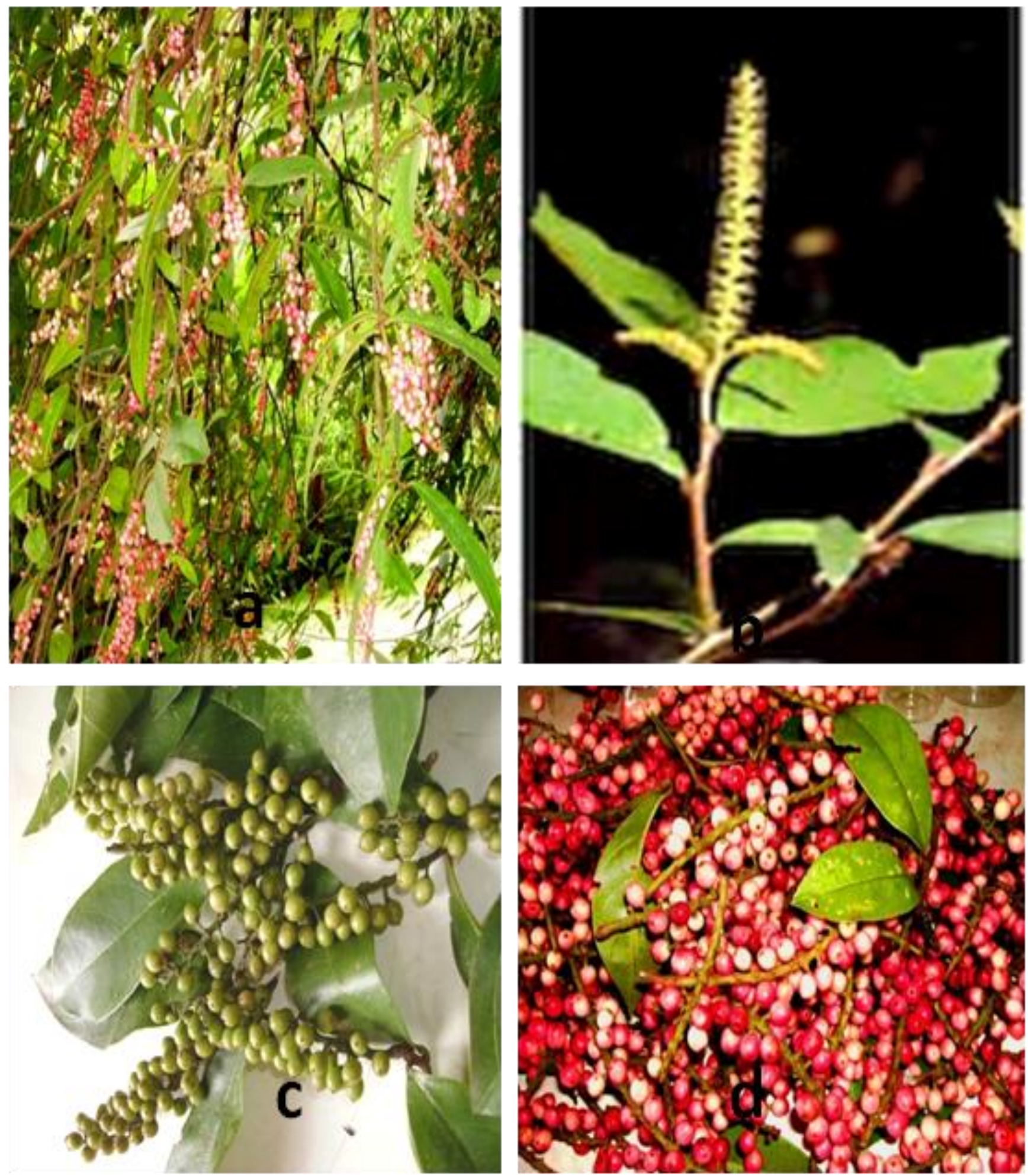
Figure.2 Lanes; a- 1kb ladder, b- no DNA band obtained when tried with other methods (Murray and Thompson,1980) c-d (Dellaporta et al., 1983), e-f (Roger and Bendich,1988),g-(Doyle and Doyle,1990), h- 1KB ladder, i and $\mathrm{j}$ - DNA band above 10kb obtained with the standardized protocol, using 2\% EB, 3M NaOAc, 3\%PVP, $8 \% \beta$-mercaptoethanol and 6 layers muslin cloth along with certain changes in the steps, k- 100bp ladder, 1- PCR amplified of 200bp amplicon, $\mathrm{m}$ - Restriction digestion with Nco1 restriction enzyme

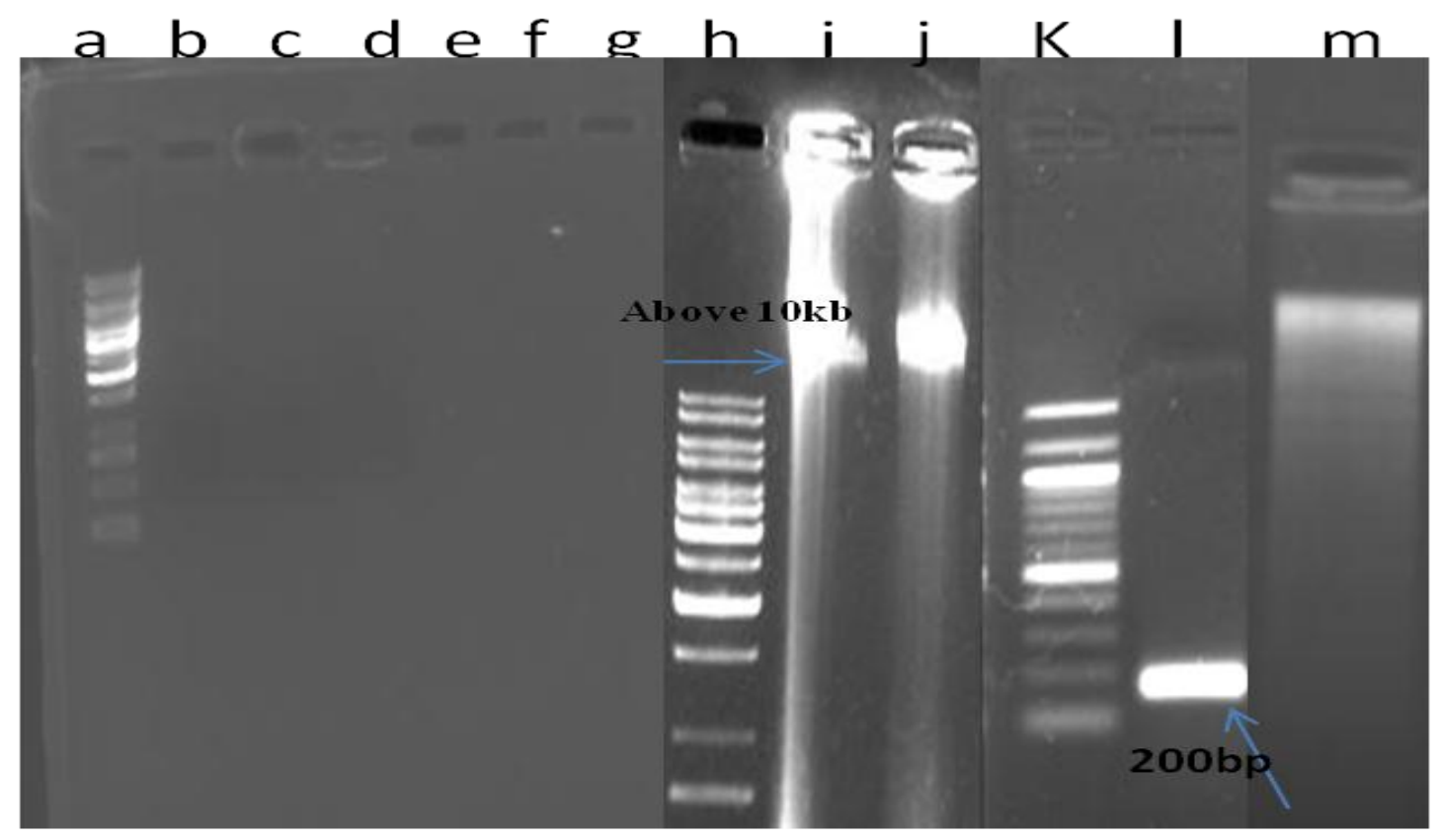

According to analyses made in Florida and Philippines the moisture content was high in the same species but low in Antidesma ghaesembilla (Black currant tree) of another species (Morton, 1987) from the present investigation which perhaps is due to variation in climatic factor (Rathore, 1981) and difference in genetic traits or species level. The decrease in moisture content in the fruits might also be due to continuous moisture loss by evaporation and respiration in fruits.

The protein quality of a food depends on its amino acid content and on the physiological utilization of specific amino acid and it has been suggested that hydrolysis of protein occurs during conversion of chloroplast to chromoplast which might have decreased protein content at ripening (Hedge and Chharia, 2004). This is reflected in Antidesma bunius fruit with low amount of protein content having $1.64 \mathrm{mg} / 100 \mathrm{~g}$. The low in protein constituents in fruits might also be associated with increase in enzymatic activities like amylase, decarboxylase, chlorophyllase and other physiological processes (Singh, 1980). From the study Antidesma bunius, a wild berry was found to have low amount of total soluble sugar, reducing sugar and non-reducing sugar present, which could be due to less hydrolysis of polysaccharide or due to low finding of ascorbic acid as revealed here which is a precursor of glucose (-6-) phosphate synthesis.

\section{Elemental profiling of Antidesma bunius}

Fruits are considered to be the chief source of minerals needed in the human diet (Hardisson et al., 2001). It is reported that the wild 
species form a good source of minerals for the local residents in different parts of the globe and play a vital role in the proper development and health of the human body. Human requires at least 49 nutrients including macro and micronutrients to meet their metabolic needs (Welch and Graham, 2004). For instance, macro-element $\mathrm{K}$ helps to maintain the normal osmotic pressure of the body fluids and the acid-base balance of the body. $\mathrm{Mg}$ is not only an essential mineral present in the bones but also in most human tissues that maintain a healthy cardiovascular system. Table 2 shows comparative mineral analyses of Antidesma bunius with other well known fruits.

From the analysis, macro-elements potassium and magnesium content was found to be very high as compared to the well known fruits and high potassium content are comparable with banana, kiwi and cherry. As the Recommended Daily Allowance (RDI) of $\mathrm{Mg}$ is $350 \mathrm{mg} / 100 \mathrm{~g}$, we suggest that Antidesma bunius is a good source of $\mathrm{Mg}$ with level at $193.25 \mathrm{mg} / 100 \mathrm{~g}$ and much higher than most of the well known fruits. In microelements, most of the elements present were high in Antidesma bunius compared to most of the fruits except very less amount of Co element. Fe present was more than the Antidesma bunius grown in Florida and Philippine (Morton, 1987) as well as from other fruits. $\mathrm{Zn}$ and $\mathrm{Cu}$ content were also found to be higher as compared to most of the well known fruits.

\section{Standardization of nucleic acid isolation}

Isolation of good quality DNA and RNA is a very essential prerequisite for any molecular analysis. The fruit reported here has not been involved in any kind of molecular investigations earlier from Manipur and also elsewhere as shown from literature search. As this fruit is scattered wild over different regions in Manipur, there is a possibility of more than one variety and species in existence. Molecular technique like barcoding for identification and isolation of genes for various pharmacologically active compounds in Antidesma bunius, good quality DNA is absolutely essential. This is the first report of DNA isolation and their quality check from Antidesma bunius. The isolation of genomic DNA from this wild fruit tree was very difficult as we presumed due to presence of many polysaccharides, polyphenols, mucilaginous substances and secondary metabolites. During isolation of high quality DNA, secondary plant products mediated DNA degradation. The presence of polyphenols, which are powerful oxidizing agents present in many plant species, can reduce the yield and purity by binding covalently with the extracted DNA making it useless for most research applications (Hemphill et al., 2006). The addition of PVP along with $\mathrm{CTAB}$ may bind to the polyphenolic compounds by forming a complex with hydrogen bonds and may help in removal of impurities to some extent from the tissue. Use of 2\%-CTAB extraction buffer, 3\% PVP, 8\% $\beta$-mercaptoethanol, in the extraction step clearly showed the presence of large amount of these substances. Our hypothesis was also proven with the report of high polyphenols contents in Antidesma bunius from Thailand showing $3550.39 \mathrm{mg} 100 \mathrm{~g}^{-1}$ fresh weight of Procyanidin B2, procyanidin B1, anthocyanins, quercetin, kaempferol, lutelin, rutin, myricetin, resveratol, ferrulic acid, vanillic acid, ellagic acid, gallic acid, caffeic acid, epicatechin and catechin (Luchai and Supachai, 2011). The protocol can be used for efficient DNA isolation and further studies on genetic variation and polymorphism in Antidesma bunius. This protocol can be used as a base for isolation of DNA from other plants having high amount of polysaccharides and polyphenols. 
Results from comprehensive analysis of biochemical contents of Antidesma bunius showing tremendous significance in nutritional aspects is very encouraging. With most of the elements present in high content, this fruit need to be popularized for consumption, utilization, and propagation along with initiation of conservation processes at all levels. Inventory of wild food resources, coupled with nutritional evaluation can only establish the non cultivated variety as real substitute for domesticated or cultivated species as it contain appreciable amounts of nutrients and energy and thus are useful food supplements. Further, various downstream molecular work can be carried out with the DNA isolation protocol standardized here yielding good quality of DNA.

\section{References}

A.O.A.C. 1970. Official method of analysis $\left(10^{\text {th }}\right.$ Ed.) Association of Official Analytical Chemists, Washington DC.

Cunningham, J.H., G. Milligan, and L. Trevisan. 2001. Minerals in Australian fruits and vegetables. A comparison of levels between the 1980's and 2000. Food Standards Australia New Zealand.

Dellaporta, S.L., Wood, J.J. and Hicks, B. 1983. A plant DNA minipreparation: version II. Plant Mol. Biol. Reporter, 1: 19-21.

Doyle, J.J. and Doyle, J.L. 1990. Isolation of Plant DNA from fresh tissue. Focus, 12, 13-15.

Dubois, M., Giller, K., Hamilton, J.K., Robers, P.A. and Smith, F., 1951. Colorimetric method for determination of sugar. Nature, 186: 167.

Edward, H. 2012. The Avon lady comes collecting Asian medicinal and food plants. May. 2012 TWN (Third world network) Briefing paper 64 . www.twnside.org.sg

Gomes, A., Das, R., Sarkhel, S., Mishra, R., Mukherjee, S., Bhattacharya, S. and
Gomes, A. 2010. Herbs and herbal constituents active against snake bite. Indian J. Experimental Biol., vol48, 856878.

Hardisson, A., Rubio, C., Martin, M., Alvarez, R. and Diaz, E. 2001. Mineral composition of the banana (Musa acuminate) from the island of Tenerife. Food Chem., 73(2): 153-161.

Haripyaree, A., Guneshwor,K. and Damayanti, M., 2010. Evaluation of antioxidant properties of some wild edible fruit extracts by cell free assays. Electronic $J$. Environ. Agri. Food Chem., 9(2): 345350.

Hazarika, T.K., Lalramchuana, and Nautiyal, B.P. 2012. Studies on wild edible fruits of Mizoram, India used as enthnomedicine. Genet Res. Crop Evol., doi: 10. 1007 /s10722-012-9799-5.

Hedge, M.V. and Chharia, A.S. 2004. Developmental and ripening physiology of guava (Psidium guajava L.) fruit I. biochemical changes. Haryana J. Horticultural Sci., 33(1/2); 62-64.

Hemphill, J., Basal, H. and Wayne, C. 2006. Screening Method for Salt Tolerance in Cotton. American J. Plant Physiol., 1: 107-112.

Henkin, R.I. and Gillis, W.T. 1997. Divergent taste responsiveness to fruit of the tree Antidesma bunius. Nature, 265: 536-537.

Hoffmann, P. 1999. The genus Antidesma (Euphorbiaceae) in Madagascar and the Comoro Islands. Kew Bull., 54: 877 885.

Jethro, A., Melanie, M., Edna, M., Esteban, S, Jr. and Felinore, A.V. 2011. Communitybased Assessment on the Plant Resource Utilization of Mt. Maculot, Cuenca, Batangas, Philippines. 2011 International Conference on Environment and Industrial Innovation IPCBEE, vol.12 IACSIT Press, Singapore p-257-262.

Jose, R.L.M., Custer, C.D. and Elmer-Rico, E.M. 2005. Biological activity of Bignay [Antidesma bunius (L.) Spreng] crude extract in Artemia salina. J. Med. Sci., 5(3): 195-198. 
Krings, U. and Berger, R.G. 2001. Antioxidant activity of some roasted foods. Food Chem., 72: 223-229.

Li, P., Susan, M., Hee-Byung, C., Tran, N,N., Nan, K., Djaja, D.S., Esperanza, J., Carcache de, B., Kari, G.C., A., Douglas, K. 2011. Bioactivity-guided Isolation of Aristolochic Acid and Other Compounds from the Roots of Antidesma bunius. Research day 2011 May 17 Biomedical Research Tower Lobby. The Ohio State University p 39.

Lowery, O.H., Rosebrough, N.J., Far, A.L. and Randall, R.J. 1951. Protein measurement with the Folin-phenol reagent. J. Biol. Chem., 193: 265-275.

Luchai, B. and Supachai, S. 2008. Analysis of anthocyanin, flavonoids, and phenolic acids in Tropical bignay berries. Int. J. Fruit Sci., vol8 (1-2): 15-34.

Luchai, B. and Supachai, S. 2011. Changes in physic- chemical properties, polyphenol compounds and antiradical activity during development and ripening of Maolung (Antidesma bunius L.Spreng) fruits. J. Fruit and Ornamental Plant Res., vol 19(1): 85-99.

Ma, D.B.A., Veronica, C.S., Erlinda, I.D., Wilma, A.H. and Mary, A.O.T. 2013. Physicochemical properties of bignay [Antidesma bunius (L.) Spreng.] wine at different stages of processing. Philippine Sci/ Lett., Vol. 6, No. 2,249-256.

Magsino, M. 2003. Don't laugh, bignay is really hard wood. Philippine Daily Inquirer. $10^{\text {th }}$ April, A1-A4.

Malhotra, S.S. and Sarkar, S.K. 1979. Effects of Sulphur dioxide on sugar and free amino acid content of pine seedling. Physiol. Plant, 47: 223-228.

Mona, E.S.K., Amani, N.H. and Heba M.H. 2013. Bioactivity of Antidesma bunius leaves (Euphorbiaceae) and their major phenolic constituents. European Scientific J., edition, vol.9, No.18, 217-228.

Morton, J.F. 1987. Bignay In: Fruits of warm climates. Published privately. Miami FL,p 210-212.

Murray, M.G. and Thompson, W.F. 1980.
Rapid isolation of high molecular weight plant DNA. Nucleic Acid Res., 8(19): 4321-4325.

Myers, N., Russell, A.M., Cristina, G.M., Gustavo, A.B., da, F. and Jennifer, K. 2000. Biodiversity hotspots for conservation priorities. Nature, vol. 403 24 Feb, 853-858.

Nelson, N. 1944. A Photometric adaptation of the Somogy's method for the determination of glucose. J. Biol. Chem., 153: 375-380.

Porebski, S., Bailey, L.G. and Baum, B.R. 1997. Modification of a CTAB DNA extraction protocol for plants containing high polysaccharide and polyphenol components. Plant Mol. Biol., Report, 15, 8-15.

Puchooa, D. 2004. A simple, rapid and efficient method for the extraction of genomic DNA from lychee (Litchi chinensis Sonn.). African J. Biotechnol., vol 3(4): 253-255.

Rathore, D.S. 1981. Physico-chemical evaluation of the fruits of four cultivars of Chinese gooseberry Actinida chinensis. Indian. J. Hort, 32: 62-65.

Rogers, S.O. and Bendich, A.J. 1988. Extraction of DNA from plant tissues. Plant Mol. Biol. Manual, A6, 1 - 10.

Rosario, M.B., Joey, G. and Myra, L.T. 2014. Antidesma bunius (bignay) fruit extract as an organic pesticide against Epilachna spp. J. Asian Scientific Res., 4(7): 320327.

Samappito, S. and Butkhup, L. 2008a. An analysis on organic acids contents in ripe fruits of fifteen Mao Lung (Antidesma bunius) cultivars, harvested from Dipterocarp forest of Phupan valley in Northeast Thailand. Pakistan J. Biol. Sci., 11(7): 974-981.

Samappito, S. and Butkhup, L. 2008b. An analysis on flavonoids, phenolics and organic acids contents in brewed red wines of both non-skin contact and skin contact fermentation techniques of Mao Luang ripe fruits (Antidesma bunius) harvested from Phupan valley in 
Northeast Thailand. Pak. J. Biol. Sci., 11(13): 1654-1661.

Shui, G. and Leong, S.L. 2002. Separation and determination of organic acids and phenolic compounds in fruit juices and drinks by high- performance liquid chromatography. J. Chromatogr, A 977, 89-96.

Singh, K. 1980. Effect of various chemical as pre and post-harvest application on Shelf life of guava at various temperatures. Ph.D. thesis, Haryana Agri. Univ. Hisar,

Sosef, M.S.M. and Prawirohatmodjo, S. 1998. Hong LT edition Timber trees: lesser known species. Plant resources of south east Asia 5(3) Backhuys Publishers., Leiden $\mathrm{p} 859$.

Subarnas, A., Diantini, A., Abdulah, R., Zuhrotun, A., Yamazaki, C., Nakazawa, M. and Koyama, H. 2012. Antiproliferative activity of primatesconsumed plants against MCF-7 human breast cancer cell lines. E3 J. Med. Res., vol 1(4), 038-043.

Suksri, A. 1999. Some agronomic and physiological aspects in growing crops in Northeast Thailand. $1^{\text {st }}$ Edn Khon Kaen University Press. Faculty of Agriculture,
Khon Kaen University, Khon Kaen 40002, Thailand, p212.

Sushma, Kh. and Shantibala, Devi, G.A. 2010. Determination of Antioxidant activity and Vitamin $\mathrm{C}$ of some wild fruits of Manipur. The Bioscan, 5(3): 501-504.

Thimmaiah, S.K. 1999. Standard Method of Bio chemical Analysis Kalyani publishers. New Delhi. p 278.

Tri Budhi Murdiati. 1991. Traditional veterinary medicine for small Ruminants in Java. Edited by- Evelyn MathiasMundy and Tri Budhi Murdiati. Indonesian Small Ruminant Network Bogor, Indonesia p -8.

Weerasak, S., Mongkol, E., Nakharin, N., Paradorn, D., Chayanid, S. and Narisa, K. 2006. Correlation analysis between total acid, total phenolic and ascorbic acid contents in fruit extracts and their antioxidant activities. Thai Pharmaceutical and Health Sci. J., vol 1(3): 196-203.

Welch, R.M. and Graham, R.D. 2004. Breeding for micronutrients in staple food crops for human nutrition perspective. $J$. Experimental Bot., 55: 353-364.

\section{How to cite this article:}

Sushma Khomdram, Shyamananda Arambam, Sharmistha Barthakur and Guruaribam Shantibala Devi. 2017. Biochemical, Nutritional Profiling and Optimization of an Efficient Nucleic Acid Isolation Protocol from Recalcitrant Tissue of Wild Edible Fruit Antidesma bunius L. spreng. Int.J.Curr.Microbiol.App.Sci. 6(4): 253-264.

doi: https://doi.org/10.20546/ijcmas.2017.604.029 